\title{
The promises and pitfalls of specifying situatedness
}

Beth Greenhough, University of Oxford, UK

March 2019

Abstract: In this piece I reflect on the promises and pitfalls of creating a more 'user friendly' and accessible summary of Haraway's 'situated knowledges'. I argue that there are clear advantages in revisiting these ideas in order to carefully consider the nature of perception and ask what is a stake in the colonization of critique. I also, however, suggest some limitations to the current reading, taking each of the gaps identified in turn and drawing on ideas from poststructuralism, multispecies ethnography and more-than-human geography, as well as my own engagements with Haraway's work. In closing I suggest there may be a case for staying with an account of situated knowledges which requires some work before you can make sense of it; an account that slows down reading and reasoning - to speculate and meander.

Key words: Haraway; situated knowledges; poststructuralism; more-than-human geographies; speculative fabulation.

Response to 'Revisiting positionality and the thesis of situated knowledge'

The aim of this paper is to generate a 'user-friendly', 'logically coherent' and 'easy to remember' ( $p$. 3) guide to situated knowledges, which are understood as an epistemological framework through which geographers may make sense of the world and our interactions with it. (Although I think the paper actually achieves far more than this, in particular through its careful consideration of the nature of perception and what is a stake in the colonization of critique, see p. 15-16). This guide is, to an extent, an endeavor that sits well with Haraway's (1988) assertion that the ability to partially translate knowledge amongst different communities is a key part of the process of situating. Expanding on Rose's $(1997,315)$ call for feminist geographers to question the authority of academic knowledge by acknowledging the 'gaps that give space to, and are affected by, other knowledges', the author draws attention to four epistemic gaps between a 'realised' world and our knowledge of it. This is then developed into a stage-by-stage guide to taking into account the partiality of our claims to knowledge and the perspectives upon which they are based. This is a very laudable object, and one my students - who often learn the language of situated knowledges far more readily than the deeper epistemological commitments it entails - should very much appreciate. Like many of the key concepts which circulate in our discipline, the situatedness of knowledge is often mentioned (usually in the form of a 'self-conscious positioning', see Rose 1997, 315), but rarely dwelt upon. I also welcome the precise, analytical approach the paper takes, seen for example in the author's careful consideration of the difference between 'perceived', 'encountered' and 'witnessed' situations (p. 15). Yet at the same time I call to mind Latour's (1999) instance on asking what is at stake in the process of translation. In more closely specifying our interpretive frameworks, what do we cut away and at what cost? Below I offer some reflections on the promises and pitfalls of more closely specifying situated knowledges.

The first gap the author identifies resonates strongly with work in non-representational theory in its call to pay attention to ways in which a focus on this present 'realised world' hampers our ability to think about and reflect on all the other possible worlds that could have materialised. (There is a lesson here, I think, for the political architects of the current Brexit crisis in the UK.) Like nonrepresentational theory, there is an insistence on the need to retain a sense that this is only one possible world amongst many possible worlds that exist in potentia; the possibility the world could have become differently, which in turn offers also the hope it still could. I would push attention to this gap still further though, to consider (as work in non-representational geographies already does) increasing attempts to colonise such futures. In an age of pandemic preparedness, disaster planning 
scenarios and contested climate futures, possible worlds are very much now part of the present. As Ben Anderson $(2010,779)$ catalogues, 'futures are: traded in futures markets, promised in contracts, expected in the form of profit, created by birth, commodified by finance capital, invested in by savers animated by a Calvinist work ethic, divined by fortune tellers, coaxed into being by theorists of diverse economies, projected by certain utopians, deterred by nation states, regularized through clock time, prophesied by evangelicals, expressed through every- day hopes, and imagined by readers of science fiction'. Perhaps what is a stake now is not the gap between realised and possible worlds, but how we might question forms of anticipatory action which are already colonising futures. Here I heed Haraway's (2014) call for speculative fabulations that might queer the pitch of white, masculine, heteronormative narratives which simultaneously open up (as possibilities) and close down (through neocolonialist imaginations) such futures.

The second 'gap' pushes us to pay attention to how our knowledges of the world are conditioned by the wider power structures within which we are embedded, our 'specific location in a matrix of social difference' (p.4). More specifically though, for Haraway this also always entails taking political responsibility for the knowledges we produce, to become 'answerable for what we learn how to see' (Haraway 1988, 583). At the same time the author suggests we need to pay attention to how our capacities to know the world are shaped by the inherent cognitive and perceptual constraints of our species' (p.4); we are limited in what it is possible for us to learn. As a researcher currently immersed in animal geographies and multispecies ethnography these constraints certainly feel very familiar (Hodgetts and Lorimer 2015; Greenhough and Roe 2019). Yet in drawing attention to the limits of our human bodies, and how these condition our encounters with the world, I am reminded of other kinds of relations within which we are embedded, and the insistence made by geographers such as Whatmore (2006) that our encounters with the world are always more-than-human. For Haraway $(1988 ; 2003)$ too our encounters with the world often, if not always, take place in companionship with nonhuman others, seen for example in her descriptions of the cellular exchanges taking place when she kisses her dog, Cayenne, or when we employ what she terms the prosthetic devices of modern technoscience. In this way the cognitive and perceptual constraints (and conversely possibilities) we have for encountering the world are not only those of our species, but of our cyborg, multispecies selves. For example, one of the most fascinating findings of recent microbiome research is the possibility that human capacities to think and feel may be shaped by our gut microbiota, or to put it more colloquially 'my microbes made me do it' (Rosenbaum 2013). Furthermore, such relationships - as beautifully described by Giraldo Herrera (2018) in his work on Shaman-as-microbiologists - can profoundly reconfigure not only how we come to know the world (epistemology), but also our understanding of what the world (and indeed knowledge) is.

The third gap draws attention to the ways in which memory shapes our encounters with the world, and is therefore a key part of how we make claims to knowledge. Yet I hesitate when the author describes memories as 'imperfect' and 'impoverished' ( $p .4)$. This language implies that there may be some kind of perfect recollection is possible, which can offer more realistic, richer account of the world, perhaps reflective of the cognitive-affective sciences on which this account draws, (something I think the author is also aware of, see note 5). In contrast, I would argue memories do not impoverish our capacities to know the world (in so far as they are always already partial). For better or worse they add to and enrich it. As Jones $(2011,876)$ argues, memories are a 'key wellspring of agency, practice/habit, creativity and imagination'. This critique in turn perhaps reflects a more general issue that emerges from orientating a reflection of the process of situating knowledges by paying attention only to the gaps which shape (and limit) the production of knowledge; namely that we lose sight of how situated knowledges also always involve the acknowledgement of 'webbed connections' (Haraway 1988), including importantly those forged between researcher and researched (see Rose 1997, 315). The paper dwells on the problems and pitfalls of co-authored memories, found in the 'post-colonial politics of translation and re- 
presentation' (page 26). I wish instead to hang onto the political possibilities of the process of narrating and sharing memories, found in a personal belief at least some of the stories we are told we are told because people want them to get heard (see for example Greenhough and Roe 2019; see also Rose 1997), an acknowledgement which carries with it a very different set of political obligations.

The final gap gestures towards our inability to relate or represent what we know, partly because some of this knowledge is inaccessible to us, subconscious, and partly because our accounts are always also socially constructed, shaped by and interpreted for the wider social networks within which we are embedded. For those of us who grew up under the influence of poststructuralism and the impact agenda, and who constantly experiment with new ways of presenting our research in diverse ways to multiple audiences, such partialities - the insistence that 'we know more than we can tell' (p.4) - are undeniable. The first element of this 'closing down' of communication is found in the 'political motivations, social pressures, fear of punishment, stigmatization and social exclusions, shame, embarrassment, self-presentational concerns, and myriad other situational factors that convince us to heavily curate and edit what we share from our private reconciliations' (p. 23-24). To the myriad other factors mentioned I would add a sense in which the spaces in which such representations are made are increasingly post-political (Swyngedouw 2009) with the effect that even if we could bring ourselves to speak, to 'confess', political debate and discussion is framed in such a way that there is no platform for our confessions. Yet I would also argue that, 'we tell more than we think we do', and I welcome the synergies the author finds between the loss and silencing of certain personal experiences and the potential of methods which bring 'the experience of the lived-and-performed situation to the foreground' (p. 26). Furthermore, there is a tendency to reflect on (and rail against) the limits in particular of words, or language, which are widely accepted now as poor substitute for the richness of the worlds they seek to relate. But words can do so much more than convey information; they can evoke feelings, emotions, responses. Words cannot materially reproduce tastes, smells or the experience of touch, but they can relate the moment when the first mouthful of ice-cream hits your tongue, makes your nostrils flare, taste buds tingle and shoulders shiver in anticipation of 'brain freeze'. Haraway's writing, rich in metaphor, woven though with feminist science fiction and careful in its choice of images is a case in point. Words subtract from the world, but they also add to it.

This brings me to my final point; what might be at stake in taking the rich, convoluted and occasionally impenetrable writing that characterises Haraway's original essay on 'situated knowledges', and indeed much of Haraway's work, and making it 'logically coherent and easy to remember' (p.3)? My students have challenged me on the readability of 'the situated knowledges essay' as a set text and I have pondered on the benefits - and I believe there are many - of an account of situated knowledges which requires some work before you can make sense of it; an account that slows down reading - and reasoning - to speculate and meander. For me there is something performative in the process of reading Haraway's texts. These are not easily comprehended; they demand (for me) a ritual that ideally involves a comfy chair, coffee and time. In her most recent book, Staying with the trouble, Haraway (2016) draws on Ursula K Le Guin's (1979) 'carrier bag theory of fiction', a cautionary tale about the risks of logical, linear narratives. I think, what I am looking to do is to hang onto the situatedness of situated knowledges; the possibility I might understand my encounters with the world (and with situated knowledges) in a haphazard, illogical, gathering kind of way, staying - as Haraway might say - with the trouble.

\section{References}


Anderson, Ben. 2010. "Preemption, Precaution, Preparedness: Anticipatory Action and Future Geographies." Progress in Human Geography 34 (6): 777-98. https://doi.org/10.1177/0309132510362600.

Giraldo Herrera, César Enrique. 2018. Microbes and Other Shamanic Beings /. Palgrave Macmillan. 10.1007/978-3-319-71318-2.

Greenhough, Beth, and Emma Roe. 2019. "Attuning to Laboratory Animals and Telling Stories: Learning Animal Geography Research Skills from Animal Technologists." Environment and Planning D: Society and Space 37 (2): 367-84. https://doi.org/10.1177/0263775818807720.

Haraway, Donna. 1988. "Situated Knowledges: The Science Question in Feminism and the Privilege of Partial Perspective." Feminist Studies 14 (3): 575. https://doi.org/10.2307/3178066.

Haraway, Donna J. 2003. The Companion Species Manifesto. Prickly Paradigm Press. https://www.press.uchicago.edu/ucp/books/book/distributed/c/bo3645022.html.

- - . 2014. "Speculative Fabulations for Technoculture's Generations." The Multispecies Salon (blog). February 28, 2014. http://www.multispecies-salon.org/haraway/.

--- 2016. Staying with the Trouble: Making Kin in the Chthulucene. Duke University Press Books.

Hodgetts, Timothy, and Jamie Lorimer. 2015. "Methodologies for Animals' Geographies: Cultures, Communication and Genomics." Cultural Geographies 22 (2): 285-95. https://doi.org/10.1177/1474474014525114.

Jones, Owain. 2011. "Geography, Memory and Non-Representational Geographies." Geography Compass 5 (12): 875-85. https://doi.org/10.1111/j.1749-8198.2011.00459.x.

Latour, Bruno. 1999. Pandora's Hope: Essays on the Reality of Science Studies. Harvard University Press.

Le Guin, Ursula K. 1979. The Language of the Night: Essays of Fantasy and Science Fiction. Putnam.

Rose, Gillian. 1997. "Situating Knowledges: Positionality, Reflexivities and Other Tactics." Progress in Human Geography 21 (3): 305-20. https://doi.org/10.1191/030913297673302122.

Rosenbaum, James T. 2013. "'The E. Coli Made Me Do It,'” November 8, 2013. https://www.newyorker.com/tech/annals-of-technology/the-e-coli-made-me-do-it.

Swyngedouw, Erik. 2009. "The Antinomies of the Postpolitical City: In Search of a Democratic Politics of Environmental Production." International Journal of Urban and Regional Research 33 (3): 601-20. https://doi.org/10.1111/j.1468-2427.2009.00859.x.

Whatmore, Sarah. 2006. "Materialist Returns: Practising Cultural Geography in and for a More-thanHuman World." Cultural Geographies 13 (4): 600-609.

https://doi.org/10.1191/1474474006cgj377oa. 